\title{
CLOSED-END REAL ESTATE FUNDS IN COMPARISON WITH OTHER INVESTMENT OPPORTUNITIES IN POLAND
}

\author{
Rafal Wolski \\ Department of Industry Economics and Capital Market \\ University of Lodz \\ e-mail: rwolski@uni.lodz.pl \\ Magdalena Załęczna \\ Department of Investment and Real Estate \\ University of Lodz \\ e-mail:mzaleczna@uni.lodz.pl
}

\begin{abstract}
The first closed-end real estate investment funds in Poland began to appear in 2004, along with the development of the capital market and the real estate market. The funds invested both in the housing market and in the commercial market. In general, they encouraged potential investors to purchase investment fund units by pointing to positive results obtained by similar funds in other countries, as well as the dynamic growth of prices in domestic real estate markets. However, the analysis of the performance of closed-end real estate funds in Poland shows that they have failed to earn satisfactory rates of return. The aim of the study was to compare their performance with the profitability of other investment instruments in the 2004 to 2014 period. In addition, the authors aimed to establish why closed-end real estate funds had failed to succeed in Poland, by analyzing, among other things, their institutional context. The study was based on a comparison of the characteristics and performance of particular funds, and also analyzed the profitability of selected alternative investments.
\end{abstract}

Key words: close-end real estate investment fund, Poland, profitability, loss.

JEL Classification: G11, R3.

Citation: Wolski R., Załęczna M., 2017, Closed-End Real Estate Funds in Comparison with other Investment Opportunities in Poland, Real Estate Management and Valuation, vol. 25, no. 1, pp. $19-47$.

DOI: 10.1515/remav-2017-0002.

\section{Introduction}

Real estate is merely one of many possibilities of investing money. It has been invested in for thousands of years because it offers a number of advantages, although it is burdened with numerous disadvantages as well. What motivates investors to invest in this type of assets is the prospect of earning income from real estate and a relatively low level of risk, combined with the protection of capital against inflation. However, real estate is highly sensitive to changes in its surroundings and in the local real property market, which is due to its fixed location, low liquidity and highly capitalintensive nature. As a result, real estate is mostly treated as a way of complementing the investment portfolio (KUCHARSKA-STASIAK 2009; HOESLI, MACGREGOR 2000).

The development of financial markets led to the emergence of new investment instruments, including those associated with real property. Attempts were made to avoid the disadvantages of investing in real estate but, at the same time, to preserve its advantages. This led to the emergence of 
indirect investment options, including the broadly defined real estate investment funds. In western countries, they had long belonged to the classics of investment instruments. In Poland, however, they did not appear until the 21st century. All over the world, and in particular in the United States, such instruments are commonly dealt with by Real Estate Investment Trusts (REIT). With their privileged tax position and professional management boards, REITs are capable of generating attractive rates of return (BLOCK 2011). This organizational and legal form is also popular in Europe. Even though domestic (national) variations of real estate investment funds exist, many countries use this model because it is well known to foreign investors.

Within the applicable legal systems, real estate funds are often divided into open-end ones and closed-end ones. There are also modifications of these two basic forms. In open-end funds, a unitholder may request redemption at any time; therefore, open-end funds should maintain a significant portion of their assets in a form which makes it possible to liquidate these assets quickly. In contrast, closed-end funds are not as strongly affected by this problem, because they are usually established for a definite period of time, whereas holders of certificates may have them redeemed by the fund at a specific time and under specific conditions. However, the financial crisis has contributed to the modification of the previously existing rules. In the German market, open-end real estate funds had very serious liquidity problems. Therefore, new legal regulations have been introduced to enable unitholders to sell their units under specific conditions within a time limit of one year (for more information, see: SEBASTIAN, STROHSAL 2012).

The authors looked into the results of investments made with units or certificates in real estate investment funds in different periods and on different markets. In particular, they tried to establish whether or not there was a correlation between these results and the results of direct real estate investments, the results of stock exchange investments and the risk level. The diversification potential of indirect investments in real estate cannot be defined because of varying time-frames and the differences between particular markets, which makes it impossible to unify results (SAGALYN 1990; CLAYTON, MACKINNON 2003; PFEFFER 2009). However, the results of investments in real estate funds are often thought to be more correlated with the securities market than with the real estate market (OPPENHEIMER, GRISSOM 1998; NISKANEN, FALKENBACH 2010).

\section{Real Estate Investment Funds in Poland}

In Poland, closed-end real estate funds can be set up pursuant to the amendment to the Act on Investment Funds, which was adopted in November 2000. The currently applicable Act upholds the rule under which a closed-end fund can make direct investments in real estate (Article 147 of the Act of 27 May 2004 on Investment Funds, Journal of Laws of 157/2014 with subsequent amendments). During the first several years since this option was introduced, the first attempts of setting up an entity of this kind were unsuccessful. These failed attempts are indicative both of the level of awareness among market participants and of the development stage of the market itself. The first unsuccessful attempt involved 645 investors, who collected less than PLN 20 million (far short of the amount of PLN 30 million required for starting the fund). In the second attempt, investors managed to collect only a half of the necessary capital (SZELĄGOWSKA 2008).

The first closed-end real estate fund, Arka BZ WBK Fundusz Rynku Nieruchomości FIZ, was approved by the supervisory authority in April 2004. The next closed-end investment fund - Skarbiec Rynku Nieruchomości FIZ was set up in 2005. It was followed by three more funds established in 2005 - two KBC funds (Index Nieruchomości and Index Światowych Nieruchomości) and Skarbiec Rynku Mieszkaniowego. In the next years, a number of new funds appeared every year. They were often established by societies in which similar funds had already been operating (KRUPA 2011; TRZEBIŃSKI 2012).

The investment strategies of the Polish funds were diverse and can be classified into three different approaches (WOLSKI, ZAŁĘCZNA 2008). The investors were mainly interested in commercial real estate because it had the potential to increase its value, and because it provided stable income from rent. They focused on residential properties with high developer margins and on real estate markets where indirect investments could be made through purchases of shares in real estate funds abroad, on the basis of prior increases in their value. A frequently mentioned investment aim was to achieve an increase in the value of assets at a level significantly exceeding the inflation rate. Some of funds specified that the net value of the fund's assets should be increased by increasing the value of real estates purchased by the fund and by partial accumulation of the revenues obtained from the real 
estate portfolio. During the period when the first real estate funds were being created, both professional and non-professional observers paid attention to the rapid increase in real estate prices. In these conditions, the generally formulated investment goal seemed easy to achieve. The funds managed to attract a number of customers by selling certificates at a low unit price and by presenting visions of the dynamic development of real estate markets. In addition, investments in such funds were thought to be profitable because the funds had been initially reporting increases in the value of certificates (KOWALKE 2012). In most cases, these funds were established for a definite period of time, which could be extended or shortened in specific circumstances. What is very significant, the construction of an investment portfolio had to be completed within 24 months of the date of registering the given public fund (statutory requirement). In 4 cases, funds created two investment portfolios: a liquid assets portfolio and real estate portfolio. With time, the latter became the dominant portfolio. After the end of the fund operation period, the funds were to be dissolved and the accumulated funds disbursed. The high value of certificates, based on periodic valuations of assets, did not necessarily correspond with a high return on investments; until the end of the fund operation period, purchasers of certificates could only dispose of them in secondary trading, at market prices, unless the statutes of these funds provided for an early redemption of a certain portion of certificates. This means that the liquidity of such investments was lower than the liquidity of, for example, stock exchange investments or purchases of units issued by open-end investment funds. According to the data relating to the closed-end investment fund "FIZ Sektora Nieruchomości BPH" obtained from the Warsaw Stock Exchange, during the entire period in which it was quoted on the Stock Exchange,the fund carried out 15,486 transactions for a total amount of PLN 13,1191.8 thousand, compared with 219,682 transactions in the shares of Echo Investment Company (totaling PLN 6,555,996 thousand) in the same period. The number of transactions in fund participation certificates is equal to only $7 \%$ of transactions in the shares of that developer and their total value is equal to $2 \%$ of the total turnover of the developer. While the low turnover may have been caused by the small capitalization, the number of transactions clearly shows that the fund's liquidity was low in comparison with the developer listed on the stock exchange. Presumably, the above example is not an exception but a rule when it comes to funds.

\section{Completed Research}

The aim of the study was to compare the profitability of investments in certificates of closed-end real estate funds with the profitability of other investment instruments in the period of 2004-2014. In addition, the authors aimed to establish why closed-end real estate funds had failed to succeed in Poland, by analyzing, among other things, their institutional context. The study was only concerned with publicly offered funds that were being liquidated. Consisting of two parts, in the first, the authors examined selected characteristic features of the funds. In the second part, they carried out a quantitative survey. The study concentrated on funds intended for liquidation, including: Arka BZ WBK FIZ Rynku Nieruchomości, Skarbiec Rynku Nieruchomości FIZ, BPH FIZ Sektora Nieruchomości, Arka BZ WBK FIZ Rynku Nieruchomości 2, BPH FIZ Sektora Nieruchomości 2 and Ipopema Rynku Mieszkaniowego FIZ (in chronological order according to the fund establishment date). Due the small number of entities included in the study, they were not classified according to when they had been set up or how long they had been operating. These factors are, nonetheless, taken into account in the conclusions.

\subsection{The Characteristics of Closed-End Real Estate Investment Funds}

The funds engaged in a wide range of investment activities. Contrary to popular opinion, however, real estates were not purchased directly by those funds, but by special purpose vehicles (investors/developers) - compare Table 1. Two funds: Skarbiec and Ipopema were mostly active in the residential market, whereas the other funds invested in commercial property markets (investments in residential properties were also permitted in some of them). The capital accumulated during the sale of certificates ranged from PLN 340 million (Arka) and PLN 332 million (BPH) to PLN 54 million (Ipopema).

The expected operation period ranged from 5 to 10 years. Such a short period is quite surprising, because real estate assets generate high transaction costs. Only investments with a high expected rate of return, which entails a higher risk level, allow one to anticipate the return on investment periods to 
be so short, taking into account all sorts of transaction costs such as, in particular, the costs of setting up and operating a real estate investment fund (management costs ranged from $2.5 \%$ to $4 \%$ of the value of assets per annum, compare Oleksy 2013) and of the liquidation of special purpose vehicles. Comparing start-up dates, one can see that both the funds established in 2004-2005 and those established much later earned negative returns on investment (from -37.2\% Arka, $-30.77 \%$ BPH to 27.44\% Ipopema) - Table 1. The only fund which earned positive yields was BPH 2, set up in 2008. Presumably, the state of the real estate markets at the time when the composition of the portfolios of real estate investment funds was being determined had a significant effect on the ultimate result. Arka and Skarbiec should have completed their portfolios in 2006 and BPH in 2007 as this was a time of recovery in real estate markets, manifesting itself with growing prices and an increase in the number of transactions. The three funds had the highest value per certificate (as calculated during the compulsory valuation of assets) in late 2008 and early 2009. Surprisingly, the results of these funds differ considerably. BPH 2, the only fund to have earned positive yields, was building its investment portfolio in 2008-2010, i.e. in the period marked by falling prices and dwindling interest in participation in transactions. As can be concluded from the valuation of assets, certificates reached their highest value at the end of the first quarter of 2013. One may be somewhat puzzled by the short operation period of the youngest fund in the group under analysis - Ipopema, whose assets achieved their highest value in late February 2012 (while building the portfolio).

As regards the real estate assets held by the funds at the time when they were being liquidated, one can easily notice that the process of selling real property and winding up special purpose vehicles is spread over time, whereas the achieved results closely depend on the real estate market situation at the time of purchase, and sale of the assets concerned. In particular, it should be stressed that, unlike movable assets, real property is influenced by its surroundings and the local/regional market situation. Funds often found it difficult to finalize their investments, as evidenced by changes in their original operation periods, which were either extended (Arka, BPH, Ipopema) or shortened (Arka 2).

Analyzing the performance of the funds, it must be emphasized that there were no differences resulting from the type of real estate - both funds operating in commercial property markets and ones operating in residential property markets had negative returns. Purchasers of certificates felt that they had been cheated. Watching the results of direct investments in real estate markets, they were convinced that they would not lose. Unfortunately, five out of six funds gave less than investors had invested.

Negative investment results were often attributed by certificate purchasers to the persons responsible for managing the real estate portfolios, as they were the ones who had selected special purpose vehicles and real estate, and had taken key investment decisions. Most of those managers were born in the 1970s. The oldest manager was born in 1959, being the only person from that age group. The youngest person took up the post of manager immediately after completing university education. In terms of their professional background, they were professionals with financial marketrelated experience. Three of them had qualifications of RICS chartered property surveyors, however, the education/experience of the managers has not been found to correlate with the yields earned. One can only conclude that, due to the short history of development of the real estate market in Poland, they were not able to rely on past experience or mechanisms. The transition period was characterized by possibilities of making use of specific "loopholes" that resulted from the insufficient number of investment products and the increased demand, enabling investors to obtain very high rates of return. However, the market conditions that exist in Poland now require fund managers to make much greater effort to achieve profit targets.

Table 1

A ranking of closed-end real estate investment funds

\begin{tabular}{|c|l|c|c|c|c|c|}
\hline $\begin{array}{c}\text { Place } \\
\text { according } \\
\text { to the rate } \\
\text { of return }\end{array}$ & $\begin{array}{c}\text { Name of the } \\
\text { fund } \\
\text { return } \\
\text { earned } \\
\text { since the } \\
\text { fund was } \\
\text { launched }\end{array}$ & $\begin{array}{c}\text { Year of } \\
\text { establishment } \\
\text { start of } \\
\text { liquidation }\end{array}$ & $\begin{array}{c}\text { Accumulated } \\
\text { capital (in } \\
\text { millions of } \\
\text { PLN) }\end{array}$ & $\begin{array}{c}\text { Number of } \\
\text { certificates }\end{array}$ & $\begin{array}{c}\text { Planned type of assets in } \\
\text { the portfolio }\end{array}$ \\
\hline 1 & $\begin{array}{l}\text { BPH FIZ } \\
\text { Sektora }\end{array}$ & $17.3 \%$ & $2008 / 2015$ & 74.0 & 747,664 & $\begin{array}{c}\text { Investments mostly in } \\
\text { commercial real estate }\end{array}$ \\
\hline
\end{tabular}




\begin{tabular}{|c|c|c|c|c|c|c|}
\hline & $\begin{array}{l}\text { Nieruchomości } \\
2\end{array}$ & & & & & $\begin{array}{l}\text { market, through the } \\
\text { intermediary of special } \\
\text { purpose vehicles. }\end{array}$ \\
\hline 2 & \begin{tabular}{|l|} 
Skarbiec FIZ \\
Rynku \\
Nieruchomości
\end{tabular} & $-6.9 \%$ & $2004 / 2014$ & 87.4 & 87,432 & $\begin{array}{l}\text { Investments in residential } \\
\text { market, through the } \\
\text { purchase and subscription } \\
\text { of shares of joint stock } \\
\text { companies, limited } \\
\text { partnerships and of limited } \\
\text { liability. }\end{array}$ \\
\hline 3 & $\begin{array}{l}\text { Arka BZ WBK } \\
\text { FIZ Rynku } \\
\text { Nieruchomości } \\
2\end{array}$ & $-21.71 \%$ & $2007 / 2015$ & 209.8 & $2,163,253$ & $\begin{array}{l}\text { Investments mostly in } \\
\text { commercial real estate } \\
\text { market, through the } \\
\text { intermediary of special } \\
\text { purpose vehicles. }\end{array}$ \\
\hline 4 & $\begin{array}{l}\text { Ipopema } \\
\text { Rynku } \\
\text { Mieszkaniowe } \\
\text { go FIZ }\end{array}$ & $-27.44 \%$ & $2010 / 2015$ & 54.0 & 540,262 & $\begin{array}{l}\text { Investments mostly in } \\
\text { residential real estate } \\
\text { market, through the } \\
\text { purchase and subscription } \\
\text { of shares of joint stock } \\
\text { companies and of limited } \\
\text { partnerships, stock in } \\
\text { limited liability companies } \\
\text { and debt securities issued } \\
\text { by the above-mentioned } \\
\text { companies }\end{array}$ \\
\hline 5 & $\begin{array}{l}\text { Arka BZ WBK } \\
\text { FIZ Rynku } \\
\text { Nieruchomości }\end{array}$ & $-30.77 \%$ & $2004 / 2014$ & 340.0 & $3,500,000$ & $\begin{array}{l}\text { Investments mostly in } \\
\text { commercial real estate } \\
\text { market through the } \\
\text { intermediary of special } \\
\text { purpose vehicles. }\end{array}$ \\
\hline 6 & \begin{tabular}{|l|} 
BPH FIZ \\
Sektora \\
Nieruchomości
\end{tabular} & $-37.2 \%$ & $2005 / 2015$ & 332.0 & $3,408,627$ & $\begin{array}{l}\text { Investments mostly in } \\
\text { commercial real estate } \\
\text { market, through the } \\
\text { intermediary of special } \\
\text { purpose vehicles. }\end{array}$ \\
\hline
\end{tabular}

Source: Own study.

\subsection{Comparative analysis}

The study was conducted on the basis of data on the six above-described closed-end real estate investment funds. The total rate of return was calculated for all these funds. The authors also examined how the rate of return had been evolving from the moment of the public issue of certificates until their redemption. They matched alternative investment options which had existed in the operation period of the funds concerned. In the case of some investments, especially bonds, it was not always possible to find an alternative investment of exactly the same duration. There were one- or two-month differences between particular investment periods, which do not seem to matter in the tenyear investment horizon. At the same time, it is worth remembering that an investor can adjust the timeframe of nearly every investment in a flexible way, also in the case of a closed-end investment fund, as long as certificates are sold in the secondary market. A rational investor will not invest his or her money in ten-year bonds for two months - although the analysis takes such cases into account to reflect at least some features of real property. The costs of the closure of such an investment must be taken into consideration too. The analyzed period sometimes differed a little, also when a given closed-end investment fund was being compared with the residential property market and the commercial property market. The main obstacle here was the lack of available data, which will be supplemented, if possible.

In many cases, the profitability of investments was compared not on the basis of specific financial instruments, but on the basis of indices. Hedonistic indices of residential property prices in the secondary market were used for the data concerning the residential property market. These indices 
are calculated and published by the National Bank of Poland. Investment profitability data pertaining to the commercial property market come from Colliers reports. In the case of stock exchange investments, on the other hand, the authors decided to analyze them on the basis of WIG, WIG20, WIG-developers and WIG-construction indices. Data unavailable in the WIG-developers index were supplemented with data from the WIG-construction index. This supplementation of data was done for the period between the first quarter of 2004 and the first quarter of 2007. It was all the more justified because the WIG-developers index did not exist then, and developer companies used to be taken into account in the WIG-construction index. Indices only serve as substitutes for investments in a given market. They are a kind of a "statistical investment", although in one case the investment can be equated with a specific asset component. The WIG20 index is the one on the basis of which index participation units were issued, as well as ETFs (Exchange Traded Fund - a passive management fund traded on the Stock Exchange). This means that an investor can make an investment easily by reproducing WIG20 index rates of return, which also makes him or her particularly valuable in a comparative analysis. All data cover the period from the 1st quarter of 2004 to the 4th quarter of 2014. However, comparisons were only made for the periods of operation of the closed-end real estate funds.

Fund profitability data were sourced from quarterly reports of these funds. Trading stock indices were taken from the website of the Warsaw Stock Exchange, whereas hedonistic price indices for the secondary residential property market were sourced from the database published by the National Bank of Poland. The rates of return for all categories of commercial properties came from Colliers reports. In the case of Arka and Arka 2 Funds, the calculation of the rates of return took into account dividend payouts. In July 2012, the Arka Fund paid a dividend of PLN 11.37 per certificate. The Arka 2 Fund paid a dividend twice. The first one amounted to PLN 4.66 and was paid in July 2012. The second one, paid out in June 2013, amounted to PLN 6.80. The indices calculated for all analyzed assets relate to the entire investment period. This means that the rates of return and other relevant indices were calculated for every fund.

The authors decided to evaluate investments using the descriptive statistics method: the rate of return, beta factors estimated against the WIG index, WIG-developers index and hedonic price index on the secondary residential property market, as well as standard deviation and semi-standard deviation. The profitability rate and the rates of systematic and total risk were thus obtained. In addition, the correlation between all successive investments and the fund was analyzed. The profitability of all investments was calculated on the basis of their stock exchange quotations or certificate values. Bond yields were calculated on the basis of the actually obtained rates of return, with account taken of the annual capitalization of interest - in conformity with the prospectuses of each bond. In addition, the following performance indicators (JOBSON, KORKIE 1981; FLAHERTY, LI 2004; PILOTTE, STERBENZ 2006) were calculated for all investments: volatility index (MARKOWITZ 1952), Sharpe's ratio (SHARPE 1966, 1994) and Jensen's alpha benchmark (JENSEN 1968). For Jensen's alpha benchmark, the profitability of investments in ten-year bonds was adopted as the risk-free rate.

The obtained results show that an investment in these funds nearly always proved to be less profitable that other investments. Essential differences were often observed between particular funds, too. It is also worth noting that the only fund to have generated profit was BPH FIZ Sektora Nieruchomości 2. On the day of its dissolution, the profit earned during the entire investment period totaled $17.3 \%$. BPH FIZ Sektora Nieruchomości, on the other hand, proved to be the worst-performing fund. It was liquidated with a loss of $37.2 \%$. Negative returns were also earned by other funds. While the losses on the capital market are not surprising, the losses of the real estate funds clash with the common view that real estate investments are safe and stable. Funds investing in real estate are commonly associated with the characteristics demonstrated by real estate, most of all, with a low risk level. In fact, however, investments in closed-end real estate funds are among the riskiest investments, with only stock exchange indices proving riskier. One exception is BPH FIZ Sektora Nieruchomości 2 a fund in liquidation, whose risk level was surpassed by the risk levels of the hedonistic price index in the entire secondary residential property market and by the hedonistic price index in the secondary markets in six cities, i.e.: Gdańsk, Gdynia, Łódź, Kraków, Poznań, Szczecin and Wrocław.

In this analysis, the impact of bonds was quite difficult to measure. It is not possible to calculate their performance indicators due to a very low or non-existing risk level. Due to the nature of interest payments and rate of return calculation method, the authors did not calculate the risk indicators for bonds. It can be assumed, however, that they are close to zero. This means that there were hardly any 
other competing investments in the periods under analysis. Bonds have to compete strongly with investments in the commercial property market. It should be noted, however, that the Colliers report from this market mostly presents the rates of return from the rental of real property. This is why this investment has a slightly different character than the other ones. The observed rates of return and profit rates are confirmed by the volatility index, Sharpe's ratio and Jensen's alpha benchmark. These indicators do not always provide identical answers; however, the conclusions drawn on their basis are quite convergent. There may be some differences in the sequence of investments resulting from different approaches to the construction of indicators. The applied formulas have been presented below:

In the case of the volatility index and Sharpe's ratio, negative values and positive values are interpreted in the opposite way. For positive values, the lower the indicator, the more effective a given investment is considered to be. For negative values, this interpretation is reversed, i.e. the higher the indicator, the better is the relative performance of the investment concerned. Such an approach could be applied when negative rates of return were acceptable for the investor. For nearly every fund, both these indicators are negative. Only BPH FIZ Sektora Nieruchomości 2, a fund in liquidation, is the volatility index positive. These patterns seem to suggest that bonds are the best form of investment. The negative Sharpe's ratio shows that investment has brought a lower rate of return than ten-year bonds. Bonds could not be analyzed using Sharpe's ratio because of the close-to-zero risk value; nevertheless, their good performance can be observed, in an indirect way, in all cases under analysis. The next form of investment are commercial investments, with invariably positive indicators, due to which they are highly rated in terms of investment efficiency. Both stock exchange indices and secondary residential property market indices sometimes achieve positive results. However, Jensen's alpha clarifies all doubts in this regard. An investor only looks for an investment with a positive value of the indicator or with one that is close to zero. A negative value indicates that the investment is inefficient in terms of risk and profit. All funds had negative alphas. In each period under analysis, positive values were recorded for investments in the commercial property market and for some of the selected stock exchange indices. Jensen's alpha remained negative for all investment periods in secondary residential property markets. Remaining on the line of securities on the basis of which Jensen constructed his alpha benchmark, the value of the relevant indicator for bonds is always close to zero. The results have been presented in Table $2 \mathrm{a}, \mathrm{b}$ and $\mathrm{c}$.

As follows from the analysis of correlation, its level is usually low. Out of 66 performed calculations, only two are above 0.5 or below -0.5; they are statistically significant at the level of 0.01 . These correlations were observed between FIZ Skarbiec and the hedonistic price index of the secondary residential property market (positive correlation) and between FIZ Arka and the rates of return from commercial properties in the commercial market (negative correlation). In theory, the correlations which relate to the real estate market and a closed-end fund should be high, but this is not the case. Moreover, 23 observations are negative, out of which 4 are statistically significant. 19 observations are positive, however, only one positive and strong correction (already mentioned earlier) is statistically significant. The results suggest that fund investments are loosely connected with the real estate market. Detailed results of the conducted analysis have been presented in Table 3.

\section{Conclusions}

The authors decided to carry out this study because they were interested in new investment opportunities that had emerged in Poland. In the period when the first funds were being set up and in the subsequent years, these investments were thought to be profitable. The first difficulties manifested themselves after the value of these assets had fallen, as reported by the funds. There was a clear problem with extending the operation period of Arka - the first closed-end real estate fund. It should be emphasized, however, that the prospectus of every fund under analysis contained a long list of risks arising from its operation and that no guarantees were given that the investment goal would be attained.

As has already been mentioned before, while the stock exchange is associated with a high level of risk and stock exchange losses are usually of no surprise to investors, purchases of certificates of investment in closed-end real estate funds were thought to be safe, due to the sense of security that is inherent in real estate. Looking at real estate funds in this context and analyzing the profit-to-risk ratio and other performance indicators, one can say that investments in these funds were the worst in the 
market. Investments in closed-end real estate funds (in 5 out of 6 funds) proved to be a trap for investors, who had expected stable profits and safety at the level similar to the one existing in the real estate market at large. Considering the yields earned by the funds, they seem to be more similar to stock exchange investments or investments in shares than to real estate investments. These findings were confirmed by correlation analysis.

Fund managers and the liquidator of FIZ Arka pointed out that these problems had been caused by the changing situation in real estate markets and by the compulsory disposal of assets after the investment time horizon had been closed. They emphasized that the geographical diversification of the assets purchased had become the proverbial millstone around their necks, because only real estate in Warsaw had not been negatively affected by the crisis and by restrictions in funding purchases, which had weakened the demand side considerably (State Control Committee 2015). This opinion does not seem to fully explain the failure of the funds that made up their portfolios at different times, so the level of changes in the prices of assets bought and sold did not follow the scheme "bought in the boom, sold in a recession" in every case.

Table 2a

Descriptive statistics of investments

\begin{tabular}{|c|c|c|c|c|c|c|c|c|c|}
\hline \multicolumn{10}{|c|}{ Okres badawczy: 2004Q3 - 2014Q2* } \\
\hline & $\mathrm{R}$ & b1 & $\mathrm{b} 2$ & b3 & $\mathrm{D}$ & $\mathrm{sD}$ & WZ & WS & $\mathrm{AJ}$ \\
\hline WIG-D & -0.77 & 1.47 & 1.00 & 0.41 & 0.21 & 0.14 & -0.27 & -7.67 & -1.93 \\
\hline WIG-B & -0.05 & 1.19 & 0.80 & 0.68 & 0.19 & 0.12 & -3.79 & -4.69 & -1.15 \\
\hline WIG20 & 0.33 & 0.89 & 0.36 & 0.08 & 0.10 & 0.06 & 0.30 & -5.08 & -0.70 \\
\hline WIG & 1.06 & 1.00 & 0.44 & 0.12 & 0.11 & 0.06 & 0.10 & 1.95 & 0.00 \\
\hline Biur & 9.73 & 0.00 & 0.00 & -0.05 & 0.01 & 0.00 & 0.00 & 889.34 & 8.89 \\
\hline Przem & 10.32 & 0.00 & 0.00 & -0.06 & 0.01 & 0.01 & 0.00 & 947.64 & 9.48 \\
\hline Hand & 16.63 & 0.00 & 0.00 & -0.07 & 0.01 & 0.00 & 0.00 & 1578.42 & 15.78 \\
\hline Index7 & 0.02 & 0.13 & 0.07 & -0.39 & 0.05 & 0.03 & 2.38 & -16.40 & -0.85 \\
\hline Index10 & 0.00 & 0.07 & 0.08 & -0.01 & 0.04 & 0.02 & -8.78 & -21.14 & -0.86 \\
\hline Index6 & 0.03 & 0.13 & 0.08 & -0.40 & 0.05 & 0.03 & 1.54 & -16.17 & -0.84 \\
\hline Index & 0.34 & 0.14 & 0.08 & 0.58 & 0.05 & 0.04 & 0.15 & -9.93 & -0.53 \\
\hline FIZ_Arka1 & -0.29 & -0.08 & -0.04 & 0.49 & 0.07 & 0.04 & -0.24 & -16.10 & -1.11 \\
\hline EDO1014 & 0.84 & 0.00 & 0.00 & 0.00 & 0.00 & 0.00 & 0.00 & $\mathrm{n} / \mathrm{d}$ & 0.00 \\
\hline
\end{tabular}

Source: Own study.

Descriptive statistics of investments

Table 2a cd.

Okres badawczy: 2008Q2 - 2015Q4*

\begin{tabular}{lllllllllll}
\hline & $\mathrm{R}$ & $\mathrm{b} 1$ & $\mathrm{~b} 2$ & $\mathrm{~b} 3$ & $\mathrm{D}$ & $\mathrm{sD}$ & $\mathrm{WZ}$ & $\mathrm{WS}$ & $\mathrm{AJ}$ \\
\hline WIG-D & -0.48 & 1.39 & 1.00 & 0.37 & 0.19 & 0.13 & -0.40 & -5.18 & 0.00 \\
\hline
\end{tabular}




\begin{tabular}{lcccccccccc}
\hline WIG-B & -0.57 & 1.14 & 0.78 & 0.64 & 0.18 & 0.11 & -0.32 & -5.97 & -0.26 \\
\hline WIG20 & -0.28 & 0.90 & 0.35 & 0.12 & 0.10 & 0.06 & -0.35 & -7.90 & -0.15 \\
\hline WIG & 0.13 & 1.00 & 0.43 & 0.15 & 0.11 & 0.06 & 0.85 & -3.44 & 0.33 \\
\hline Biur & 4.71 & 0.00 & 0.00 & -0.05 & 0.01 & 0.00 & 0.00 & 420.37 & 4.20 \\
\hline Przem & 4.71 & 0.00 & 0.00 & -0.06 & 0.01 & 0.00 & 0.00 & 420.23 & 4.20 \\
\hline Hand & 7.08 & 0.00 & 0.00 & -0.07 & 0.01 & 0.00 & 0.00 & 657.56 & 6.58 \\
\hline Index7 & 0.01 & 0.13 & 0.07 & -0.39 & 0.04 & 0.03 & 5.68 & -12.51 & -0.41 \\
\hline Index10 & -0.07 & 0.08 & 0.07 & -0.01 & 0.04 & 0.02 & -0.56 & -14.47 & -0.52 \\
\hline Index6 & -0.01 & 0.12 & 0.08 & -0.41 & 0.05 & 0.03 & -4.75 & -10.36 & -0.43 \\
\hline Index & -0.12 & 0.14 & 0.08 & 0.58 & 0.05 & 0.03 & -0.42 & -12.55 & -0.53 \\
\hline FIZ_Arka2 & -0.11 & -0.11 & -0.03 & 0.45 & 0.05 & 0.03 & -0.46 & -12.31 & -0.69 \\
\hline EDO0618 & 0.51 & 0.00 & 0.00 & 0.00 & 0.00 & 0.00 & 0.00 & $n / d$ & 0.00 \\
\hline
\end{tabular}

Source: Own study

Table 2b

Descriptive statistics of investments

Okres badawczy: 2005Q3 - 2015Q4*

\begin{tabular}{lcccccccccc}
\hline & $\mathrm{R}$ & $\mathrm{b} 1$ & $\mathrm{~b} 2$ & $\mathrm{~b} 3$ & $\mathrm{D}$ & $\mathrm{sD}$ & $\mathrm{WZ}$ & $\mathrm{WS}$ & $\mathrm{AJ}$ \\
\hline WIG-D & -0.04 & 1.39 & 1.00 & 0.37 & 0.19 & 0.13 & -4.52 & -3.56 & -0.03 \\
\hline WIG-B & 0.12 & 1.14 & 0.78 & 0.64 & 0.18 & 0.11 & 1.50 & -2.86 & 0.02 \\
\hline WIG20 & -0.26 & 0.90 & 0.35 & 0.12 & 0.10 & 0.06 & -0.38 & -8.97 & -0.48 \\
\hline WIG & 0.37 & 1.00 & 0.43 & 0.15 & 0.11 & 0.06 & 0.29 & -2.37 & 0.21 \\
\hline Offices & 9.71 & 0.00 & 0.00 & -0.05 & 0.01 & 0.00 & 0.00 & 907.40 & 9.07 \\
\hline Industry & 9.86 & 0.00 & 0.00 & -0.06 & 0.01 & 0.00 & 0.00 & 922.33 & 9.22 \\
\hline Commerce & 16.14 & 0.00 & 0.00 & -0.07 & 0.01 & 0.00 & 0.00 & 1550.51 & 15.51 \\
\hline Index7 & 0.00 & 0.13 & 0.07 & -0.39 & 0.04 & 0.03 & 36.19 & -15.85 & -0.57 \\
\hline Index10 & 0.02 & 0.08 & 0.07 & -0.01 & 0.04 & 0.02 & 2.56 & -15.49 & -0.58 \\
\hline Index6 & 0.02 & 0.12 & 0.08 & -0.41 & 0.05 & 0.03 & 2.97 & -12.36 & -0.56 \\
\hline Index & 0.36 & 0.14 & 0.08 & 0.58 & 0.05 & 0.03 & 0.14 & -5.60 & -0.21 \\
\hline
\end{tabular}




\begin{tabular}{llllllllll}
\hline FIZ_BPH1 & -0.37 & -0.21 & -0.06 & 0.50 & 0.07 & 0.04 & -0.19 & -14.39 & -1.10 \\
\hline EDO0915 & 0.64 & 0.00 & 0.00 & 0.00 & 0.00 & 0.00 & 0.00 & $\mathrm{n} / \mathrm{d}$ & 0.00 \\
\hline
\end{tabular}

Source: Own study

Table $2 b$ cd.

Descriptive statistics of investments

\begin{tabular}{|c|c|c|c|c|c|c|c|c|c|}
\hline \multicolumn{10}{|c|}{ Okres badawczy: 2008Q2 - 2015Q4* } \\
\hline & $\mathrm{R}$ & b1 & b2 & b3 & $\mathrm{D}$ & $\mathrm{sD}$ & WZ & WS & AJ \\
\hline WIG-D & -0.48 & 1.39 & 1.00 & 0.37 & 0.19 & 0.13 & -0.40 & -4.62 & 0.11 \\
\hline WIG-B & -0.57 & 1.14 & 0.78 & 0.64 & 0.18 & 0.11 & -0.32 & -5.37 & -0.16 \\
\hline WIG20 & -0.28 & 0.90 & 0.35 & 0.12 & 0.10 & 0.06 & -0.35 & -6.82 & -0.04 \\
\hline WIG & 0.13 & 1.00 & 0.43 & 0.15 & 0.11 & 0.06 & 0.85 & -2.46 & 0.44 \\
\hline Offices & 4.71 & 0.00 & 0.00 & -0.05 & 0.01 & 0.00 & 0.00 & 431.17 & 4.31 \\
\hline Industry & 4.71 & 0.00 & 0.00 & -0.06 & 0.01 & 0.00 & 0.00 & 431.03 & 4.31 \\
\hline Commerce & 7.08 & 0.00 & 0.00 & -0.07 & 0.01 & 0.00 & 0.00 & 668.35 & 6.68 \\
\hline Index7 & 0.01 & 0.13 & 0.07 & -0.39 & 0.04 & 0.03 & 5.88 & -9.82 & -0.30 \\
\hline Index10 & -0.05 & 0.08 & 0.07 & -0.01 & 0.04 & 0.02 & -0.75 & -11.32 & -0.40 \\
\hline Index6 & 0.01 & 0.12 & 0.08 & -0.41 & 0.05 & 0.03 & 3.91 & -7.73 & -0.30 \\
\hline Index & -0.12 & 0.14 & 0.08 & 0.58 & 0.05 & 0.03 & -0.42 & -10.37 & -0.42 \\
\hline FIZ_BPH2 & 0.17 & -0.06 & -0.06 & -0.01 & 0.04 & 0.02 & 0.23 & -5.66 & -0.27 \\
\hline EDO0618 & 0.40 & 0.00 & 0.00 & 0.00 & 0.00 & 0.00 & 0.00 & $\mathrm{n} / \mathrm{d}$ & 0.00 \\
\hline
\end{tabular}

Source: Own study

Table 2c

Descriptive statistics of investments

Okres badawczy: 2006Q3 - 2015Q3*

\begin{tabular}{lccccccccc}
\hline & R & b1 & b2 & b3 & D & sD & WZ & WS & AJ \\
\hline WIG-D & -0.42 & 1.39 & 1.00 & 0.37 & 0.19 & 0.13 & -0.45 & -3.63 & -0.57 \\
\hline WIG-B & -0.46 & 1.14 & 0.78 & 0.64 & 0.18 & 0.11 & -0.39 & -4.01 & -0.63 \\
\hline WIG20 & -0.18 & 0.90 & 0.35 & 0.12 & 0.10 & 0.06 & -0.55 & -4.46 & -0.37 \\
\hline WIG & 0.18 & 1.00 & 0.43 & 0.15 & 0.11 & 0.06 & 0.61 & -0.77 & 0.00 \\
\hline
\end{tabular}




\begin{tabular}{lccccccccc}
\hline Offices & 2.34 & 0.00 & 0.00 & -0.05 & 0.01 & 0.00 & 0.00 & 207.82 & 2.08 \\
\hline Industry & 2.28 & 0.00 & 0.00 & -0.06 & 0.01 & 0.00 & 0.00 & 201.56 & 2.02 \\
\hline Commerce & 3.29 & 0.00 & 0.00 & -0.07 & 0.01 & 0.00 & 0.00 & 302.26 & 3.02 \\
\hline Index7 & -0.02 & 0.13 & 0.07 & -0.39 & 0.04 & 0.03 & -2.29 & -7.05 & -0.27 \\
\hline Index10 & 0.00 & 0.08 & 0.07 & -0.01 & 0.04 & 0.02 & -14.79 & -6.69 & -0.26 \\
\hline Index6 & -0.01 & 0.12 & 0.08 & -0.41 & 0.05 & 0.03 & -7.02 & -5.44 & -0.26 \\
\hline Index & -0.10 & 0.14 & 0.08 & 0.58 & 0.05 & 0.03 & -0.52 & -7.21 & -0.35 \\
\hline FIZ_Ipopema & -0.27 & -0.08 & -0.11 & -0.09 & 0.05 & 0.01 & -0.18 & -10.78 & -0.55 \\
\hline EDO1220 & 0.26 & 0.00 & 0.00 & 0.00 & 0.00 & 0.00 & 0.00 & $\mathrm{n} / \mathrm{d}$ & 0.00 \\
\hline
\end{tabular}

Source: Own study

Table 2c cd.

Descriptive statistics of investments

Okres badawczy: 2004Q1 - 2014Q3*

\begin{tabular}{lcccccccccc}
\hline & $\mathrm{R}$ & $\mathrm{b} 1$ & $\mathrm{~b} 2$ & $\mathrm{~b} 3$ & $\mathrm{D}$ & $\mathrm{sD}$ & $\mathrm{WZ}$ & $\mathrm{WS}$ & $\mathrm{AJ}$ \\
\hline WIG-D & 0.03 & 1.42 & 1.00 & 1.30 & 0.20 & 0.14 & 6.05 & -4.04 & -1.19 \\
\hline WIG-B & 0.22 & 1.16 & 0.78 & 1.60 & 0.18 & 0.12 & 0.81 & -3.44 & -0.93 \\
\hline WIG20 & 0.28 & 0.89 & 0.36 & 0.68 & 0.10 & 0.06 & 0.35 & -5.58 & -0.80 \\
\hline WIG & 1.11 & 1.00 & 0.43 & 0.85 & 0.11 & 0.06 & 0.10 & 2.45 & 0.00 \\
\hline Offices & 12.55 & -0.01 & 0.00 & -0.04 & 0.00 & 0.00 & 0.00 & $\mathrm{n} / \mathrm{d}$ & 11.71 \\
\hline Industry & 13.15 & -0.01 & 0.00 & -0.05 & 0.01 & 0.00 & 0.00 & 1231.25 & 12.32 \\
\hline Commerce & 22.21 & -0.01 & 0.00 & -0.06 & 0.01 & 0.00 & 0.00 & 2137.01 & 21.37 \\
\hline Index7 & 0.00 & 0.13 & 0.07 & 0.45 & 0.04 & 0.03 & 29.76 & -20.99 & -0.87 \\
\hline Index10 & 0.00 & 0.08 & 0.07 & 0.27 & 0.04 & 0.02 & -10.93 & -21.11 & -0.87 \\
\hline Index6 & -0.01 & 0.12 & 0.08 & 0.48 & 0.05 & 0.03 & -7.60 & -16.95 & -0.88 \\
\hline Index & 0.35 & 0.14 & 0.08 & 1.00 & 0.05 & 0.04 & 0.14 & -9.75 & -0.53 \\
\hline FIZ_Skarb & -0.07 & -0.05 & -0.02 & 0.35 & 0.03 & 0.02 & -0.43 & -30.34 & -0.90 \\
\hline EDO1014 & 0.84 & 0.00 & 0.00 & 0.00 & 0.00 & 0.00 & 0.00 & $\mathrm{n} / \mathrm{d}$ & 0.00 \\
\hline
\end{tabular}

Source: Own study. 
$\mathrm{R}$ - total return in the period of the audited FIZ

b1 - beta calculated relatively to the index WIG

b2 - beta calculated relatively to the index WIG-Developers

b3 - beta calculated relatively to the hedonic index of flat prices on the second hand market (according to NBP -

Polish National Bank)

D - total risk during the operation of the tested FIZ measured by the standard deviation

$\mathrm{SD}$ - total risk during the operation of the tested FIZ measured by the semi - standard deviation

WIG-D - WIG-Developers

WIG-B - WIG-Construction

WIG20 - WIG20

WIG - WIG

Index7 - NBP hedonic index of housing prices in the secondary market for the 7 cities: Gdańsk, Gdynia, Łódź,

Kraków, Poznań, Warsaw, Wrocław

Index10 - NBP hedonic index of housing prices in the secondary market for 10 cities: Białystok, Bydgoszcz,

Katowice, Kielce, Lublin, Olsztyn, Opole, Rzeszów, Szczecin, Zielona Góra

Index6 - NBP hedonic index of housing prices in the secondary market for the 6 cities without Warsaw: Gdańsk,

Gdynia, Łódź, Kraków, Poznań, Szczecin, Wrocław

Index - NBP hedonic index of housing prices in the secondary market for the all provincial cities without Torun,

with Gdynia

FIZ_Skarb - Skarbiec Real Estate Investment Closed End Found in liquidation

FIZ_Arka1 - Arka BZ WBK Real Estate Investment Closed End Found in liquidation

FIZ_Arka2 - Arka BZ WBK 2 Real Estate Investment Closed End Found in liquidation

FIZ_BPH1 - BPH FIZ Real Estate Investment Closed End Found in liquidation

FIZ_BPH2 - BPH FIZ 2 Real Estate Investment Closed End Found in liquidation

FIZ_Ipopema - IPOPEMA Housing Investment Closed End Found in liquidation

EDOXXYY - ten-year national bonds, where $X X$ is a month of expiration, and $Y Y$ the two last digits of the

expiration year

* Research period marked by the pattern: YYYYQX where YYYY is a year, and QX is a quarter of a examined year.

** It was assumed that each risk measure for bonds is equal to 0.

Table 3

Pearson correlation

\begin{tabular}{|c|c|c|c|c|c|c|c|c|c|c|c|c|}
\hline & & WIGD & WIGB & WIG20 & WIG & Biura & Przemysł & Handel & Index7 & Index10 & Index6 & Index \\
\hline \multirow[t]{2}{*}{ FIZ_Arka1 } & $\mathrm{p}$ & -0.139 & -0.023 & -0.131 & -0.172 & -0.108 & -0.103 & $-0.513^{* *}$ & -0.046 & -0.162 & -0.026 & 0.335 \\
\hline & $\mathrm{N}$ & 39 & 39 & 39 & 39 & 39 & 39 & 39 & 31 & 31 & 31 & 31 \\
\hline \multirow[t]{2}{*}{ FIZ_Arka2 } & $\mathrm{p}$ & -0.131 & -0.159 & -0.184 & -0.219 & 0.370 & 0.359 & 0.077 & -0.093 & 0.065 & -0.085 & 0.050 \\
\hline & $\mathrm{N}$ & 29 & 29 & 29 & 29 & 28 & 28 & 28 & 29 & 29 & 29 & 29 \\
\hline \multirow[t]{2}{*}{ FIZ_BPH2 } & $\mathrm{p}$ & -0.261 & $-0.614^{* *}$ & -0.114 & -0.181 & 0.121 & 0.183 & 0.234 & -0.211 & $-0.450^{*}$ & -0.183 & -0.277 \\
\hline & $\mathrm{N}$ & 30 & 30 & 30 & 30 & 28 & 28 & 28 & 29 & 29 & 29 & 29 \\
\hline \multirow[t]{2}{*}{ FIZ_BPH1 } & $\mathrm{p}$ & -0.173 & -0.213 & $-0.345^{*}$ & $-0.336^{*}$ & 0.194 & 0.109 & 0.012 & -0.215 & -0.169 & -0.149 & 0.113 \\
\hline & $\mathrm{N}$ & 41 & 41 & 41 & 41 & 39 & 39 & 39 & 36 & 36 & 36 & 36 \\
\hline \multirow[t]{2}{*}{ FIZ_Skarb } & $\mathrm{p}$ & 0.102 & 0.227 & -0.024 & -0.042 & $-0.336^{*}$ & -0.171 & $-0.409^{* *}$ & 0.193 & 0.188 & 0.230 & $0.688^{* *}$ \\
\hline & $\mathrm{N}$ & 43 & 43 & 43 & 43 & 43 & 43 & 43 & 33 & 33 & 33 & 33 \\
\hline \multirow[t]{2}{*}{$\begin{array}{l}\text { FIZ_ } \\
\text { Ipopema }\end{array}$} & $\mathrm{p}$ & -0.247 & $-0.459^{*}$ & -0.147 & -0.134 & 0.082 & 0.082 & 0.082 & -0.177 & -0.204 & -0.244 & -0.157 \\
\hline & $\mathrm{N}$ & 22 & 22 & 22 & 22 & 20 & 20 & 20 & 21 & 21 & 21 & 21 \\
\hline
\end{tabular}


** correlation significant at a level of 0.01 (two-sided)

* correlation significant at a level of 0.05 (two-sided).

\section{References}

Source: Own study.

BLOCK R. L., 2011, Investing in REITs: Real Estate Investment Trusts, Vol. 141, John Wiley \& Sons.

FLAHERTY S., LI J, 2004, Composite Performance Measures, Chinese Economy, 37/3: 39-66.

Hoesli M., MaCGregor B.D., 2000, Property Investment: Principles and Practice of Portfolio Management, Pearson Education.

JENSEN M.C., 1968, The Performance of Mutual Funds in the Period 1945-1964, Journal of Finance, 23: 389417.

JOBSON J.D., KORKIE B.M., 1981, Performance Hypothesis Testing with the Sharpe and Treynor Measures, Journal of Finance, 36: 889-908.

KANCElaria SEJMU, BIURO KOMISJI SEJMOWYCH, Pełny zapis przebiegu posiedzenia Komisji do spraw Kontroli Państwowej (Full record of the meeting of the Commission for State Control), nr $169 \mathrm{z}$ dnia 5 sierpnia 2015 r. (No. 169 of 5 August 2015).

KOWALKE K., 2012, Fundusze inwestycyjne rynku nieruchomości w Polsce (Real Estate Investment Funds in Poland), Studia i Materiały Towarzystwa Naukowego Nieruchomości (Studies and Materials of Real Estate Scientific Society) 20. Vol. 3, 199-209.

KRUPA D., 2011, Fundusze inwestycyjne na rynku nieruchomości (Investment Funds on the Real Estate Market), in: Siemińska E.(ed.)." Inwestowanie na rynku nieruchomości (Investing on the Real Estate Market), Poltex, Warszawa.

KUCHARSKA-STASIAK E., 2009, Nieruchomość w gospodarce rynkowej (Real Estate in the Market Economy), Wydawnictwo Naukowe PWN (Polish Scientific Publishers PWN).

MARKOWITZ H. M., 1952, Portfolio Selection, Journal of Finance, 7/1:77-91.

NiskANEN J., FALKENBACH H., 2010, REITs and Correlations with Other Asset Classes: A European Perspective, Journal of Real Estate Portfolio Management 16.3, 227-239.

OLEKSY P., 2013, Wysokość opłat za zarządzanie a efektywność polskich funduszy nieruchomości (The Value of Fees for the Management and Efficiency of Polish Real Estate Funds), Annales Universitatis Mariae Curie-Skłodowska, Sectio H. Oeconomia 47.3 (XLVII), 465-476.

OpPENHEIMER P., GrISSOM T., 1998, Frequency Space Correlation between REITs and Capital Market Indices, Journal of Real Estate Research 16.3, 291-310.

PFEFFER T., 2009, Performance of REITs: a Sector-and Company-Based Analysis of Links and Time Lags between Real Estate Market Cycles, Earnings, and Pricing of REITs, Vol. 49, Müller.

PilotTE E.A., STERBENZ F.P., 2006, Sharpe and Treynor Ratios on Treasury Bonds, Journal of Business, 79:149-180.

SAGALYN L., 1990, Real Estate Risk and the Business Cycle: Evidence from Security Markets, Journal of Real Estate Research, 5.2, 203-219.

Sebastian S., Strohsal T., 2012, German Open-End Real Estate Funds in: Just T., Maennig W. (ed.), Understanding German real estate markets, Springer.

SHARPE W., 1966, Mutual Fund Performance, Journal of Business 39: 110-138.

SHARPE W., 1994, The Sharpe Ratio, Journal of Portfolio Management, 21: 49-58.

SZELĄGOWSKA A., 2008, Rozwój funduszy rynku nieruchomości na polskim rynku finansowym a tendencje światowe (The Development of Real Estate Funds on the Polish Financial Market and Global Trends), in: Antkiewicz S., Kalinowski M. (red.), Innowacje finansowe (Financial Innovations), CeDeWu Wydawnictwo Fachowe (CeDeWu Expert Publishing), Warszawa.

TRZEBIŃSKI A. A., 2012, Ewolucja polskiego rynku funduszy nieruchomości (The Evolution of the Polish Real Estate Funds Market), in: Świadek A.(ed.), Gospodarka XXI wieku. Innowacyjność, ekonomika i organizacja (The economy of XXI century. Innovation, economics and organization), Naukowe Wydawnictwo IVG (IVG Scientific Publishing), Szczecin.

ZAŁĘCZNA M., WOLSKI R, 2008, Zamknięte fundusze nieruchomości jako nowoczesna forma inwestowania (Closed-end Real Estate Investment Funds as a Modern Form of Investing), Studia i Materiały Towarzystwa Naukowego Nieruchomości (Studies and Materials of the Polish Real Estate Scientific Society) 16.4, 19-36. 